Irina B. Pavlova

Doctor of Philology

Senior Researcher

Institute of World Literature

Russian Academy of Science

e-mail: antologia1@yandex.ru

Moscow, Russia

ResearcherID AAO-8719-2020

ORCID 0000-0002-0006-0156

\title{
THE COLOR SYMBOLISM IN THE WORKS OF M. SALTYKOV-SHCHEDRIN
}

Summary: The article is devoted to the symbolism of color in the works of Saltykov-Shchedrin. Color is a fundamental phenomenon of existence; various sciences, including literary criticism, study it. It is connected with the ideological conception of the work, with art space; it bears a visual function, emotionally colors the world depicted by a writer, enriches, makes it more complex. SaltykovShchedrin's use of color is connected with the satirist's talent to see the reality in the "concentration of evil". In the works of the writer, Russia appears to be ambivalent: it is a field of the rampage of the elements, energies, and the realm of deadness, of slumber, which is presented in the writer's palette by two achromatic colors. White and gray are distinguished by special semantic saturation. In Saltykov-Shchedrin's works, their symbolism is seen in a negative aspect: white represents coldness, despair, insipidity; gray - poverty, sadness, rough weather. In the descriptions of the environment, these colors are accompanied by images of snow, rain, fog, which in turn are connected with the motifs of death, doom, and emptiness of life. Many of the satirist's works starting from his early stories, Contradictions, Brusin, are emotionally charged in such a way. White and gray colors define the peculiarity of the artistic space of many works of Saltykov-Shchedrin. In the epilogue of the series Provincial Sketches, the ground appears covered with a white shroud. The tragedy of this

Color is a fundamental phenomenon of existence. It is studied by natural, exact sciences, philosophy, psychology, various humanitarian areas: art history, linguistics, literary criticism ${ }^{1}$. In a work of art, color serves to reveal the ideological content, has

1. Isaev A., Teplykh D. Philosophy of Color: the Phenomenon of Color in Mentality and Art. Moscow, 2011. image is compounded in the cycle of Well-Intentioned Speeches. Snow as a white shroud is the writer's constant metaphor. Almost always when describing Russian expanses, monotonous, dull colors dominate in the works of the satirist. White color expands the space to the infinity overwhelming a man; gray increases the feeling of hopelessness. Saltykov-Shchedrin's landscape correlates with the unclear fate of Russia, with mournful events in the national history, a fading aristocratic landlord class. These colors are associated with moral issues in the novelchronicle The Golovlyov Family. In the tale Night of Christ, white and gray serve as the concentration of world evil. However, gray does not have only negative energy - the "gray tones" of the Motherland cause the writer to feel "love to the pain in the heart". Golden color in the idiomatic expression "Golden age", an age of harmony and prosperity, used by the socialists-utopians, to whose ideals Saltykov-Shchedrin always remained true, stand as the antagonist of white and gray. Color is one of the mental units forming the concept sphere of Saltykov-Shchedrin's creative work; it reflects the diversity of the author's thinking, the philosophy of the artist-satirist, the worldview of a particular age, and the national picture of the world.

Keywords: color as a phenomenon, literary study, white, gray, the idea of the work, artistic depiction, art space, concept sphere of Saltykov-Shchedrin art.

a visual function, function of spatial perception, it emotionally colors the world depicted by the writer, enriching, and making it more complex. Generally, these functions coexist.

Coloristics plays an important role in SaltykovShchedrin's poetics. Its originality is determined by the nature of the writer's work: the social satirist's 
feature of talent to see the surrounding reality in the "concentration of evil". We will not find a variety of colors in Saltykov-Shchedrin's work: his use of color is very modest. In the works of the writer, Russia appears to be ambivalent: it is a field of the rampage of the elements, energies, passions, and the realm of deadness, of slumber. Two related, achromatic colors in the artist's palette are connected with the later hypostasis. White and gray (a mixture of white and black), which are important components of the natural world depicted by the writer, are semantically rich. They occupy a dominant position in his landscape description. In Saltykov-Shchedrin's works, the symbolism of these colors is seen in a negative aspect: white represents coldness, despair, insipidity; gray - poverty, boredom, sadness, rough weather.

In the descriptions of the environment, these colors accompany images of snow, ice, rain, fog, which in turn are associated with the motives of death, doom, emptiness of life. Many of the satirist's works are emotionally colored, starting with the early story A Complicated Case (1848), created as part of the "natural school". Dampness, either rain or snow are the main indications of St. Petersburg in this work. The atmosphere of the capital is depressing, joyless: a piercing wind is constantly blowing, it is raining with wet snow, the colors are always dark. There is no clear sky in the city, no warmth from the sun is felt. Death is the only outcome for the protagonist, wretched Michulin. Another story, Brusin (1847), is set either in the capital or in a country house near St. Petersburg. Here, the landscape is almost always weary-boring, gray, with often drizzling rain. The condition of the world around is similar to the empty, dull life of the central character, a man devoid of character, of an individuality, an initiative by the "order of things" during the reign of Nikolay.

White and gray colors determine the uniqueness of the artistic space of Saltykov-Shchedrin's many works. In the chapter "The Road. Instead of an Epilogue" from the series Provincial Essays (1856), the traveling protagonist-narrator complains about the annoying snow dust "holding the person in some kind of forced imprisonment" (II, 462). Whiteness not only loses a romantic halo but also acts as a sign of death, conquering the surrounding space. Falling snow is melting on the face, water is unpleasantly flowing down. The first snow, a silvery cloud are poetic, beautiful but only from afar, that is, they are deceiving. The plains are not breathing, they are covered with a white shroud, and to a weary traveler it seems that a dead man is about to emerge from under the shroud. This work depicts Russia on the verge of reform; however, after eighteen years in the Well-Intentioned Speeches (1872-1876), nothing changes in Russian life, it bears a mournful cover funeral sheets. One of the most tragic landscapes in Russian literature arises: "Shrouds, shrouds, shrouds! A shroud is lying on the fields and meadows; a shroud has chained the river; a dormant forest is in a shroud; a Russian village is hiding under a shroud. $<\ldots>\mathrm{A}$ desert, hopeless, heartbreaking desert ... Here is a circular whirlwind, it has bored a snow cover - and as if something started to groan. $\langle\ldots$. . It seems that the whole neighborhood is full of mournful murmurs, that the wind is capturing random sounds that come across the road and is collecting them into one general groan ...

Shrouds and groans ..." 2 (XI, 343).

Snow as a white shroud is a constant metaphor in the works of Saltykov-Shchedrin.

In almost all satirist's works, with rare exceptions, minor tones sound in the description of Russian open spaces, monotonous, muddy, dull colors prevail, they are bored with grief, they are guarded, immersed in a heavy, unforgettable dream, like a mortal. People in the vast expanses experience some kind of orphanhood, desolation ("оброшенность") according to the writer, they are almost disappearing. White color expands the space to an overwhelming immensity, sucking a person.

White is a sinister infinity, without perspective, without tones. For the author, coldness, depressing, deathly whiteness is a certain stable sign of Russian space. Winter landscape descriptions depicted by Saltykov-Shchedrin are especially joyless, and torment is everywhere.

The satirical writer often presents his native landscape as numb, with snowy distances that intersect with endless roads. It correlates with unclear destinies of Russia, the mournful events of national history, and the extinction of the noble-landlord class. In the novel-chronicle The Golovlyov Family (18751880), the doom of the old way of life is emphasized, in particular, by spatial signs: the landowner's house of the Golovlevs is imaginary, ghastly; however, nature around is also lifeless. "November is

2. Saltykov-Shchedrin M.E. Collected Works: in 20 volumes. V. XI. Moscow, 1971. P. 343. In the future, in the text, references to this publication are given with the volume and page in brackets. 


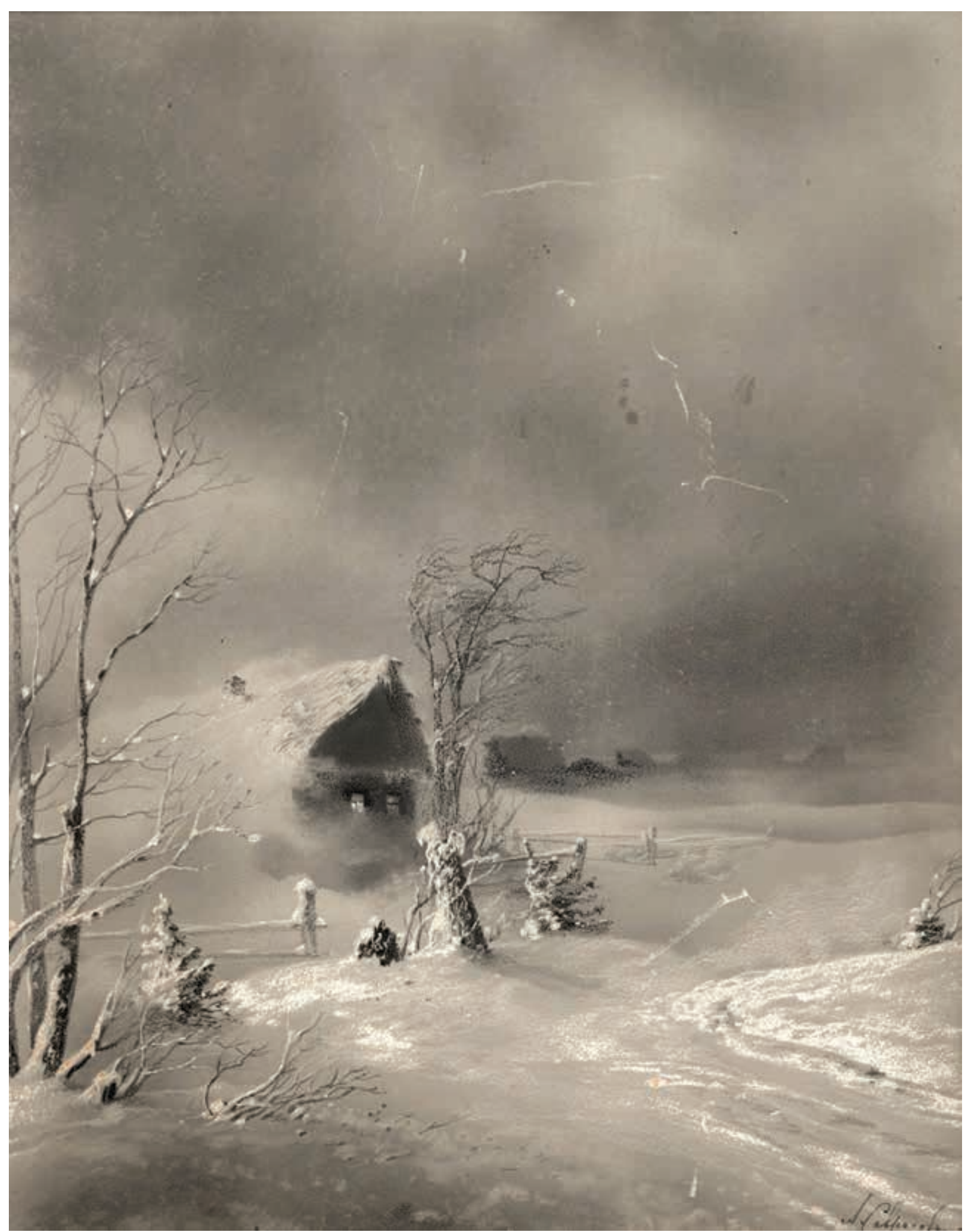

IIl. 1. A. K. Savrasova. Winter evening. Ground tinted cardboard, pencil, scratching. State Museum of Fine Arts of the Republic of Tatarstan

coming to an end, the ground all around is covered with a white shroud. It is night and blizzard; a sharp, cold wind is drilling snow, sweeping snowdrifts in an instant, swallowing everything that comes in its way, and filling the whole neighborhood with a cry" (XIII, 106-107).
The problem of the mysterious Russian fate is being addressed by using both white color and gray in its darkest shades, enhancing the feeling of hopelessness. "The impenetrable darkness with a lead canopy has bristled and is lying heavily over these huts, and in this darkness old Saturn reigns supreme, 
eating his children alive. The son who is an inseparable witness of father's silent cowardice or cowardly deceit, can he take out anything else from his observations except his own cowardice and craftiness? .. And in this way it passes, this darkness, from one generation to another, strengthening more and more steadily the damned toils in which they are tangled" (VII, 267-268). Saltykov-Shchedrin often imagined that Russian life was moving fatally in a vicious circle, which was not known how to break, and that the oppression of centuries-old prejudices was aggravated, lead color suppressing, absorbing the light, and there was no glimmer of hope for a change for the better.

White and gray colors are also associated with the moral problems of the novel-chronicle The Golovlyov Family. Snow and wind, twilight met Porfiry Golovlev, when, driven by belated remorse, he went to his mother's grave to apologize: "outside, the wind was howling and a March wet snowstorm was whirling round, sending whole showers of thawed snow into the eyes" (XIII, 262). He died in the midst of the raging elements of snow and rain, failing to overcome them. Porfiry Golovlev did not receive complete forgiveness: he was too long a Judas.

The fairy tale Night of Christ (1886), with a subtitle "A Legend", is one of the most striking works of the last period of Saltykov-Shchedrin's life. Thus, the author links it with the folk tradition and at the same time reinterprets this tradition in many ways. Here, gray and white colors seem to serve as the concentration of world evil. The tale begins with a piercingly bitter Russian landscape typical of the satirist's creative work: a plain numbing under a snow sheet in the deep silence of the night; a silent forest crushed by hoarfrost; a dark sky strewn with stars; cold, quivering light pouring onto the ground; mourning spots of trees drowned in snow heaps. A "stamp of loneliness, abandonment, and squalor" is on everything (XVI-1, 206). "Everything is fettered, helpless and silent as if crushed by an invisible but formidable bondage" (ibid). "Suddenly, the ring of midnight bells is heard, and the neighborhood comes to life. Gray, tormented by poverty people are stretching along the road. Their humility and sighing are what they have brought to the Risen God" (ibid).

However, gray does not only have negative energy. For Saltykov-Shchedrin, monochrome gray represents humility, poverty, the squalor of life, something that causes an almost paradoxical love "to heart- ache". Already in the cycle Provincial Essays, a sad, gray landscape of central Russia appears (chapter "Madame Muzovkina"). Saltykov-Shchedrin's sense of closeness with his homeland is based on grief. In Provincial Essays, for example, such is the soulful explanation of the narrator-hero about his feelings for the humble Russian nature with which he was related, gave her the best part of himself. For the narrator, sad colors of the motherland are the highest value, a precious asset. "... even if I will be surrounded with any luxurious nature, thrown any transparent blue sky on this nature, I will always find sweet gray tones of my homeland everywhere, because I always and everywhere have them in my heart, because my soul keeps them as its best asset" (II, 152).

Gold, although it is mentioned relatively rarely in Shchedrin's writings and is included in the idiomatic expression "golden age", is the antagonist of white and gray colors. According to Saltykov-Shchedrin, in his youth, he instinctively clung to France of SaintSimon, Cabe, Fourier, Louis Blanc, and especially George Sand, who influenced his ideological development. "It is from there the faith in humanity poured into us, from there the confidence shone for us that the "golden age" is not behind us, but ahead of us... In a word, everything good, everything desired and loving, everything came from there" (XIV, 111-112). Gold symbolizes the sun, magnificence, wisdom, vitality. And the "golden age", according to mythological ideas, is a period of prosperity, harmony for humanity. Philosopher, sociologist, reformer A. de Saint-Simon believed that he was not in the past, but ahead, in the future and depended on public improvement. Enlightener Saltykov-Shchedrin remained faithful to the hopes of the Utopian socialists, democrats till the end. He always had the hope for the transformation of Russian reality, that the dusk enveloping life would disappear, the life would sparkle with bright colors, Russian open spaces would awaken from sleep, "true, united and binding for all Truth would come and the whole world would shine " (XVI-1, 218). At the same time, the artist's ideal aspirations were inextricably linked with skepticism and self-irony: the "golden age" could appear in a satirical context but as an object of the passive: in the fairy tale Eagle-Patron, the "golden age", the enlightenment period set by the cruel predator Eagle for small birds, quickly ended.

One of the mental units that form the conceptual sphere of Saltykov-Shchedrin's creativity is color, which, along with concepts such as the state, peo- 
ple, history, city, space, land, reflects the originality of the author's thinking, the life philosophy of the satirical artist, his axiology, epistemology, ontolo- gy, the worldview of a certain era, the national picture of the world ${ }^{3}$.

3. Likhachev D. 1993. "The Conceptual Sphere of Russian Language", The News of the Russian Academy of Science. The Series of literature and language, pp. 3-9.

\section{REFERENCES}

1. Isaev A., Teplykh D. 2011. Filosofiya tsveta: fenomen tsveta $v$ mentalitete $i$ iskusstve [Philosophy of Color: the Phenomenon of Color in Mentality and Art], Moscow (in Russian)

2. Likhachev, D. 1993. "Kontseptual'naya sfera russkogo yazyka" ["The Conceptual Sphere of Russian Language"], Izvestiya Rossiyskoy akademii nauk. Seriya literatury i yazyka [The News of the Russian Academy of Science. The Series of literature and language], pp. 3-9. (in Russian)

3. Saltykov-Shchedrin, M. 1965-1977.Works. V. II, XI, XIII, XIV, XVI, Moscow (in Russian)

4. Guijarro Lasheras, Rodrigo. 2019. "On Imaginary Content Analogies in Musico-Literary Imitation." CLCWeb: Comparative Literature and Culture 21.4 DOI: 10.7771/1481-4374.3152 (in English)

5. Menting, H. A. 2000. "The Reading of the Heart: AntiAesopian Language in the Work of M.E. SaltykovŠčedrin", Russian Literature, vol. 48, no 4, pp. 389-407 DOI: 10.1016/S0304-3479(00)80028-9 (in English)

6. Zavlunov, D., IZubkov, K. 2020. " The Roles of the Censor: New Perspectives on Censorship in NineteenthCentury Russia", Russian Literature, vol. 113, pp. 1-5 DOI: 10.1016/j.ruslit.2020.04.002 (in English)

7. Tuliakova, N. 2020. " Literary Legend in Early NineteenthCentury Russian Literature: Genre Labeling and Genre Formation", Russian Literature, vol. 111-112, pp. 35-59 DOI: 10.1016/j.ruslit.2020.03.002 (in English)

8. Nivat, G. 2003. "The Russian Landscape as Myth", Russian Studies in Literature, vol. 39, no. 2, pp. 51-70 DOI: 10.2753/RSL1061-1975390251 (in English)

9. Pavlova, I. B. 2016. "The destiny of Two Volonteers", Texts. Art and Literature scientific and analytical journal, Bruxelles, no. 4, pp. 79-84. (in English)
10. Pavlova, I. B. 2017. "Katekhizis - ob"yekt vnimaniya L. N. Tolstogo pri formirovanii zamysla romana o dekabristakh" ["Catechism is the object of attention of L. N. Tolstoy in the formation of the intent of the novel about the Decembrists"], Nauchno-analiticheskiy zhurnal Dom Burganova. Prostranstvo kul'tury [Art Literature Scientific and Analytic Journal Burganov House. The Space of Culture], no. 1, pp. 18-29. (in Russian)

11. Pavlova, I. B. 2018. "M. Ye. Saltykov-Shchedrin i I. S. Turgenev. K istorii vzaimootnosheniy" ["M.E. SaltykovShchedrin and I. S. Turgenev. To the history of relationships"], Nauchno-analiticheskiy zhurnal Dom Burganova. Prostranstvo kul'tury [Art Literature Scientific and Analytic Journal Burganov House. The Space of Culture], no. 4, pp. 116-124. (in Russian)

12. Pavlova, I. B. 2018. "Tema stradaniya tvari i yeye reprezentatsiya u L. N. Tolstogo, M. Ye. SaltykovaShchedrina, F. M. Dostoyevskogo, N. A. Nekrasova" ["The theme of the creature's suffering and its representation by L. N. Tolstoy, M.E. Saltykov-Shchedrin, F. M. Dostoevsky, N. A. Nekrasova "], Russkaya literatura Russian literature, no. 6, pp. 52-56. (in Russian)

13. Pavlova, I. B. 2019. "Udivitel'nyy ekfrasis opery v romane-epopeye L. N. Tolstogo "Voyna i mir" ["The amazing ecfrasis of the opera in the epic novel L.N. Tolstoy "War and Peace""], Nauchno-analiticheskiy zhurnal Dom Burganova. Prostranstvo kul'tury [Art Literature Scientific and Analytic Journal Burganov House. The Space of Culture], no. 2, pp. 117-128. (in Russian) 
Ирина Борисовна Павлова

доктор филологических наук

старший научный сотрудник

Института мировой литературы Российской академии наук

e-mail: antologia1@yandex.ru

Россия, Москва

ResearcherID AAO-8719-2020

ORCID 0000-0002-0006-0156

DOI: 10.36340/2071-6818-2020-16-2-91-99

\section{СИМВОЛИКА ЦВЕТА В ПРОИЗВЕДЕНИЯХ М. Е. САЛТЫКОВА-ЩЕДРИНА}

Аннотация: Содержание статьи посвящено символике цвета в произведениях М.Е. Салтыкова-Щедрина. Цвет - фундаментальный феномен бытия, его исследуют различные науки, в том числе и литературоведение. Он связан с идейным замыслом произведения, с художественным пространством, несёт изобразительную функцию, эмоционально окрашивает изображённый писателем мир, обогащает, усложняет его. Использование цвета Салтыковым-Щедриным связано с особенностями таланта писателя-сатирика видеть окружающую действительность в «сгущениях зла». В произведениях писателя Русь предстаёт двойственной: она - поле буйства стихий, энергий, и царство мертвенности, усыпления, которое представлено в палитре художника двумя ахроматическими красками. Особая семантическая насыщенность отличает белый и серый цвета. Их символика выступает у Салтыкова-Щедрина в негативном аспекте: белый - холод, отчаяние, безжизненность, серый - бедность, тоска, ненастье. В описаниях внешней среды эти цвета сопутствуют образам снега, дождя, тумана, которые, в свою очередь, связаны с мотивами смерти, обречённости, пустоты жизни. Так, эмоционально окрашены многие произведения сатирика, начиная с ранних повестей «Противоречия» и «Брусин». Белый и серый цвета определяют своеобразие художественного пространства многих произведений Салтыкова-Щедрина. В эпилоге цикла «Губернские очерки» земля предстаёт покрытой белым саваном. Трагизм этого изображения усугубляется в цикле «Благонамеренные

Цвет является фундаментальным феноменом бытия. Его исследуют естественные, точные науки, философия, психология, различные направления гуманитарной мысли: искусствоведение, речи». Постоянная метафора у писателя: снег - белый саван. Почти всегда при описании русских просторов в произведениях сатирика преобладают монотонные, тусклые краски. Белый цвет расширяет пространство до подавляющей человека бесконечности, серый - усиливает ощущение безысходности. Пейзаж у Салтыкова-Щедрина соотносится с непрояснёнными судьбами России, со скорбными событиями национальной истории, с угасанием дворянско-помещичьего класса. Эти цвета оказываются связаны и с нравственной проблематикой в романе-хронике «Господа Головлёвы». В сказке «Христова ночь» белый и серый служат как бы концентрацией мирового зла. Но серый цвет обладает не только негативной энергией - «серенькие тона» родины вызывают у писателя «любовь до боли сердечной». Антагонистом белого и серого выступает золотой цвет в идиоматическом выражении «золотой век» (век гармонии и благоденствия), используемом социалистами-утопистами, а Салтыков-Щедрин всегда оставался верен их идеалам. Цвет - одна из ментальных единиц, образующая концептосферу творчества Салтыкова-Щедрина и отражающая своеобразие авторского мышления, философию художника-сатирика, мировоззрение определённой эпохи, национальную картину мира.

Ключевые слова: феномен цвета, литературоведение, белый, серый, идейный замысел, изобразительность, художественное пространство, кониептосфера творчества Салтыкова-Щедрина. лингвистика, литературоведение ${ }^{1}$. Цвет в художественном произведении служит раскрытию

1. Исаев А. А., Теплых Д.А. Философия цвета: феномен цвета в мышлении и творчестве. М.: Флинта, 2011. 
идейного содержания, несёт функцию изобразительную, пространственного восприятия, эмоционально окрашивает изображаемый писателем мир, обогащая и усложняя его. Как правило, эти функции сосуществуют.

Колористика играет заметную роль в поэтике Салтыкова-Щедрина. Её своеобразие определяется характером творчества писателя: свойство таланта социального сатирика видеть окружающую действительность в «сгущениях зла». У Салтыкова-Щедрина мы не найдём пиршества красок: его цветопись очень скупа. В произведениях сатирика Русь предстаёт двойственной: она - поле буйства стихий, энергий, страстей и царство мертвенности, усыпления. С её последней ипостасью связаны два родственных, ахроматических цвета в палитре художника. Особая семантическая насыщенность отличает белый и серый (смешение белого и чёрного), которые являются важными составляющими изображаемого писателем природного мира, занимают доминирующее положение в его пейзажных картинах. Символика этих цветов выступает у художника в её негативном аспекте: белый - холод, отчаяние, безжизненность, серый - бедность, скука, тоска, ненастье.

В описаниях внешней среды названные цвета сопутствуют образам снега, льда, дождя, тумана, которые, в свою очередь, связаны с мотивами смерти, обречённости, пустоты жизни. Так, эмоционально окрашены многие произведения сатирика, начиная с ранней повести «Запутанное дело» (1848), созданной в рамках «натуральной школы». Главная примета Петербурга в этом произведении - сырость, то ли дождь, то ли снег. Атмосфера столицы представлена гнетущей, безотрадной: постоянно дует пронзительный ветер, идёт дождь, мокрый снег, всегда тёмный колорит. В городе не бывает ясного неба, не чувствуется солнечного тепла. Единственный исход для главного героя, обездоленного Мичулина, - смерть. В другой повести — «Брусин» (1847) - действие происходит то в столице, то на даче под Петербургом. Здесь пейзаж почти всегда томительноскучный, серый, часто моросит дождь. Состояние окружающего мира аналогично бессодержательной, тусклой жизни центрального персонажа безнатурного человека, лишённого «порядком вещей» николаевского царствования индивидуальности, инициативы.

Белый и серый цвета определяют своеобразие художественного пространства многих про- изведений Салтыкова-Щедрина. В главе «Дорога. (Вместо эпилога)» цикла «Губернские очерки» (1856) путешествующий герой-рассказчик жалуется на раздражающую чувства снежную пыль, «содержащую человека в каком-то насильственном заключении» (II, 462). Белизна не только лишается романтического ореола, но и выступает приметой смерти, покорившей себе всё окружающее пространство. Падающий снег тает на лице, водные потоки неприятным образом текут вниз. Первый снег, серебристое облако поэтичны, красивы лишь издали, то есть обманчивы. Равнины не дышат, они покрыты белым саваном, и утомлённому путнику кажется, что вот-вот из-под савана встанет мертвец. В этом произведении изображена Россия на пороге реформ, но спустя восемнадцать лет в «Благонамеренных речах» (1872-1876) ничто не меняется в русской жизни, на ней лежит скорбный покров - погребальные пелены. Возникает один из самых трагических пейзажей в отечественной литературе: «Саваны, саваны, саваны! Саван лежит на полях и лугах; саван сковал реку; саваном окутан дремлющий лес; в саван спряталась русская деревня. <..> Пустыня, безнадёжная, надрывающая сердце пустыня... Вот налетел круговой вихрь, с визгом взбуравил снежную пелену - и кажется, словно что-то застонало. <...> Мнится, что вся окрестность полна жалобного ропота, что ветер захватывает попадающиеся по дороге случайные звуки и собирает их в один общий стон ...

Саваны и стоны ...»² (XI, 343).

Постоянная метафора в произведениях Салтыкова-Щедрина: снег - белый саван.

Практически во всех (за редким исключением) произведениях сатирика в описании русских просторов звучат минорные тона, преобладают монотонные, мутные, тусклые краски, от них веет тоской, они страждут, погружены в тяжёлый, непробудный сон, подобный смертному. Люди среди бескрайних пространств испытывают какое-то сиротство, «оброшенность», по выражению писателя, почти уничтожаются. Белый цвет расширяет пределы до подавляющей необъятности, засасывающей человека.

Белое - это дурная бесконечность, без перспективы, без тонов. Холод, угнетающая, мертвенная белизна для художника - некий устойчивый

2. Салтыков-Щедрин М.Е. Собр. соч.: в 20 т. Т. ХІ. М., Худ. лит., 1971. С. 343. В дальнейшем ссылки на это издание даются в тексте с указанием в скобках тома и страницы. 
признак русского пространства. Зимние природные картины, изображённые Салтыковым-Щедриным, особенно безотрадны, и повсюду разлита мука.

Родной пейзаж часто предстаёт у писателясатирика как оцепеневшие, заснеженные дали, которые пересекаются бесконечными дорогами, и соотносится с непрояснёнными судьбами России, скорбными событиями национальной истории, с угасанием дворянско-помещичьего класса. Обречённость старого уклада жизни в романехронике «Господа Головлёвы» (1875-1880) подчёркивается, в частности, пространственными приметами: помещичий дом господ Головлёвых мнимость, выморочное место, но и внешняя среда также безжизненна. «Ноябрь в исходе, земля на неоглядное пространство покрыта белым саваном. На дворе ночь и метелица; резкий, холодный ветер буровит снег, в одно мгновение наметает сугробы, захлестывает всё, что попадается на пути, и всю окрестность наполняет воплем» (XIII, 106-107).

Проблема загадочной русской судьбы решается с использованием как белого, так и серого цвета, причём в самых мрачных его оттенках, усиливающих ощущение безысходности. «Непроницаемая тьма свинцовым пологом ощетинилась и отяжелела над этими хижинами, и в этой тьме безраздельно царствует старый Сатурн, заживо поедающий детей своих. Сын, безотлучный свидетель безмолвного малодушия или трусливого лукавства отца, может ли вынести из своих наблюдений что-нибудь иное, кроме собственного малодушия и лукавства?.. И таким образом переходит она, эта тьма, от одного поколения к другому, всё круче и круче закрепляя проклятые тенёта, которыми они спутаны» (VII, 267-268). Салтыкову-Щедрину часто представлялось, что русская жизнь фаталистически движется по замкнутому кругу, который неизвестно, как разорвать, и что гнёт вековых предрассудков всё усугубляется, свинцовый колорит подавляет, поглощает свет, и нет никакого проблеска надежды на изменения к лучшему.

Белый и серый цвета оказываются связаны и с нравственной проблематикой романа-хроники «Господа Головлёвы». Снег и ветер, сумерки встретили Порфирия Головлёва, когда тот, движимый запоздалым раскаянием, отправился на могилку к маменьке испросить прощения: на «дворе выл ветер и крутилась мартовская мокрая метелица, посылая в глаза целые ливни талого снега»
(XIII, 262). Он так и погиб среди разбушевавшейся стихии снега и дождя, не сумев преодолеть её. Порфирий Головлёв не получил полного прощения: он слишком долго был Иудушкой.

Одним из ярких произведений последнего периода жизни Салтыкова-Щедрина является сказка «Христова ночь» (1886), имеющая подзаголовок «Предание». Тем самым автор связывает её с фольклорной традицией и одновременно во многом эту традицию переосмысливает. Здесь серый и белый цвета как бы служат концентрацией мирового зла. Сказка начинается пронзительно-горькой русской пейзажной картиной, типичной для творчества сатирика: цепенеющая под снежной пеленой среди глубокого безмолвия ночи равнина, молчаливый лес, придавленный инеем, тёмное небо, усыпанное звёздами, льющими на землю холодный, трепещущий свет, траурные точки деревьев, утонувших в сугробах. На всём «печать сиротливости, заброшенности и убожества» (XVI-1, 206). «Всё сковано, беспомощно и безмолвно, словно задавлено невидимой, но грозной кабалой» (там же). «Вдруг раздаётся гудение полночных колоколов, и окрестность оживает. По дороге потянулись серые, замученные нищетою люди. Своё смирение и воздыхания вот что они несли Воскресшему Богу» (там же).

Но серый цвет обладает не только негативной энергией. Для Салтыкова-Щедрина монохромный серый - это смирение, бедность, убожество окружающей жизни, нечто, вызывающее почти парадоксальную любовь «до боли сердечной». Уже в цикле «Губернские очерки» возникает грустный, серенький пейзаж средней России (глава «Госпожа Музовкина»). У Салтыкова-Щедрина чувство близости с Россией основано на скорби. Таково, например, проникновенное объяснение героя-рассказчика в «Губернских очерках» в его чувствах к скромной русской природе, с которой он сроднился, отдал ей лучшую часть себя. Печальные краски отчизны для повествователя - высшая ценность, драгоценное достояние. «...окружите какою хотите роскошною природой, накиньте на эту природу какое угодно прозрачное и синее небо, я всё-таки везде найду милые мне серенькие тоны моей родины, потому что я всюду и всегда ношу их в моём сердце, потому что душа моя хранит их как лучшее свое достояние (II, 152).

Антагонистом белого и серого цветов выступает золотой, хотя он сравнительно редко 
упоминается в щедринских произведениях и входит в идиоматическое выражение «золотой век». По признанию Салтыкова-Щедрина, в годы молодости он инстинктивно «прилепился к Франции Сен-Симона, Кабе, Фурье, Луи Блана и в особенности Жорж-Занда», повлиявших на его идейное становление. «Оттуда лилась в нас вера в человечество, оттуда воссияла нам уверенность, что «золотой век» находится не позади, а впереди нас... Словом сказать, всё доброе, всё желанное и любвеобильное - всё шло оттуда» (XIV, 111112). Золото символизирует солнце, великолепие, мудрость, жизненную силу. А «золотой век», согласно мифологическим представлениям, - период благоденствия, гармонии для человечества. Философ, социолог, реформатор А. де Сен-Симон считал, что он находится не в прошлом, а впереди, в будущем, и зависит от общественного благоустройства. Упованиям социалистов-утопистов демократ, просветитель Салтыков-Щедрин оставался верен до конца, в нём никогда не угасала надежда на преображение русской действительности, на то, что сумрак, окутывающий жизнь, рассеется, она заиграет яркими красками, русские просторы пробудятся от сна, «объявится настоящая, единая и для всех обязательная Правда, придёт и весь мир осияет» (XVI-1, 218). При этом идеальные устремления неразрывно связаны у художника со скепсисом и самоиронией: «золотой век» мог появиться в сатирическом контексте, но в качестве объекта страдательного: в сказке «Орёл-меценат» «золотой век», т.е. период просвещения, установленный жестоким хищником Орлом для мелких птиц, быстро закончился.

Одной из ментальных единиц, образующих концептосферу творчества Салтыкова-Щедрина, является «цвет», который наряду с такими концептами, как, например государство, народ, история, город, простор, земля, отражает своеобразие авторского мышления, жизненную философию художника-сатирика, его аксиологию, гносеологию, онтологию, мировоззрение определённой эпохи, национальную картину мира ${ }^{3}$.

3. См.: Лихачёв Д. С. Концептосфера русского языка // Известия РАН. Серия лит. и яз., 1993. С. 3-9.

\section{БИБЛИОГРАФИЯ}

1. Исаев А.А., Теплых Д.А. Феномен цвета: феномен цвета в мышлении и творчестве. М., 2011.

2. Лихачёв Д.С. Концептосфера русского языка // Известия РАН. Серия литературы и языка, 1993. С. 3-9.

3. Салтыков-Щедрин М.Е. Собр. соч.: в 20 т. Тт. II, VII, XI, XIII, XIV, XVI- 1.

4. Guijarro Lasheras, Rodrigo. «On Imaginary Content Analogies in Musico-Literary Imitation.» CLCWeb: Comparative Literature and Culture 21.4 (2019): https:// doi.org/10.7771/1481-4374.3152

5. Menting, H. A. 2000. «The Reading of the Heart: AntiAesopian Language in the Work of M.E. SaltykovŠčedrin», Russian Literature, vol. 48, no 4, pp. 389-407 https://doi.org/10.1016/S0304-3479(00)80028-9

6. Zavlunov, D., IZubkov, K. 2020. «The Roles of the Censor: New Perspectives on Censorship in Nineteenth-Century Russia», Russian Literature, vol. 113, pp. 1-5 https://doi. org/10.1016/j.ruslit.2020.04.002

7. Tuliakova, N. 2020. " Literary Legend in Early Nineteenth-Century Russian Literature: Genre Labeling and Genre Formation», Russian Literature, vol. 111-112, pp. 35-59 https://doi.org/10.1016/j.ruslit.2020.03.002
8. Nivat, G. 2003. «The Russian Landscape as Myth», Russian Studies in Literature, vol. 39, no. 2, pp. 51-70 https://doi.org/10.2753/RSL1061-1975390251

9. I. Pavlova. The destiny of Two Volonteers // Texts. Art and Literature scientific and analytical journal. Bruxelles, 2016, № 4, р. 79-84.

10. И. Павлова. Катехизис - объект внимания Л. Н. Толстого при формировании замысла романа о декабристах // Дом Бурганова. Пространство культуры, 2017, № 1, с. 18-29.

11. И. Павлова. М.Е. Салтыков-Щедрин и И.С. Тургенев. К истории взаимоотношений // Дом Бурганова. Пространство культуры, 2018, № 4, с. 116-124.

12. И. Павлова. Тема страдания твари и ее репрезентация у Л.Н. Толстого, М.Е. Салтыкова-Щедрина, Ф. М. Достоевского, Н. А. Некрасова // Русская словесность, 2018, № 6, с. 52-56.

13. И. Павлова. Удивительный экфрасис оперы в романеэпопее Л.Н. Толстого «Война и мир» // Дом Бурганова. Пространство культуры, 2019, № 2, с. 117-128. 